\title{
Clinical and pathological importance of vacA allele heterogeneity and cagA status in peptic ulcer disease in patients from North Brazil
}

\author{
Luisa Caricio Martins $/{ }^{+}$, Tereza Cristina de O liveira Corvelo, Samia Demachki*, \\ Marialva TF Araujo*, Mônica Baraúna Assumpção**, \\ Simone Cristina Araujo Jucá Vilar*** $* * * *$, Felipe Bonfim Freitas, \\ Hivana Patricia Melo Barbosa, Amanda Alves Fecury, Renata Kelly Costa do Amaral, \\ Sidney Emanuel Batista dos Santos*****
}

\begin{abstract}
Laboratório de Imunogenética, Departamento de Genética, Centro de Ciências Biológicas, Universidade Federal do Pará, Rua Augusto Correa s/nº Campus Universitário do Guamá, 66075-110 Belém, PA, Brasil *Departamento de Patologia,

**Departamento de Endoscopia, Hospital Universitário João de Barros Barreto Belém, PA, Brasil ***Departamento de Endoscopia, Hospital Ofir Loiola, Belém, PA, Brasil *****Departamento de Endoscopia, Hospital Universitário Betina de Ferro Souza, Belém, PA, Brasil ******aboratório de Genética Humana e Médica, Departamento de Patologia, Universidade Federal do Pará, Belém, PA, Brasil

We have examined the prevalence of gene cagA and vacA alleles in 129 patients, 69 with gastritis and 60 with peptic ulcer diseases from North Brazil and their relation with histopathological data. vacA and cagA genotype were determined by polymerase chain reaction. Hematoxylin-eosin staining was used for histological diagnosis. 96.6\% of the patients were colonized by Helicobacter pylori strains harboring single vacA genotype (nont-mixed infection). Among them, $11.8 \%$ had subtype s1a, $67.8 \%$ had subtype s1b, and $17 \%$ subtype s2. In regard to the middle region analysis, $m 1$ alleles were found in $75.4 \%$ and $m 2$ in $21.2 \%$ of patients. The cagA gene was detected in $78 \%$ patients infected with $\mathrm{H}$. pylori and was associated with the s1-ml vacA genotype. The $\mathrm{H}$. pylori strains, vacA slb ml/cagA-positive, were associated with increased risk of peptic ulcer disease and higher amounts of lymphocytic and neutrophilic infiltrates and the presence of intestinal metaplasia. These findings show that cag A and vacA genotyping may have clinical relevance in Brazil.
\end{abstract}

Key words: Helicobacter pylori - peptic ulcer - vacA alleles - cagA status - Brazil

Helicobacter pylori infection is the major cause of chronic superficial gastritis in humans, an important etiological factor in the pathogenesis of peptic ulcers (PUD) and some forms of gastric cancer (Dunn et al. 1997). However, most people who harbor $H$. pylori are asymptomatic, and only a few patients infected with this bacterium develop either PUD or gastric cancer (Nomura et al. 1994). The variability of clinical manifestations is associated with several factors such as specific organism virulence factor, host immunological factor, and environmental influences, or their combination (Taylor \& Blaser 1991, Atherton et al. 1997).

Cytotoxin VacA and protein CagA are the two major virulence markers usually associated with $H$. pylori pathogenicity. The vacuolating cytotoxin ( $\mathrm{VacA}$ ) induces the formation of intracellular vacuoles in epithelial cell lines (Cover \& Blaser 1992, Atherton et al. 1995). Besides its direct cell-damaging effect in vitro, VacA also plays a major role in inducing cytoskeletal changes, apoptosis, suppression of epithelial proliferation, and migration (Pai et al.

\footnotetext{
Financial support: Sectam, Capes

+Corresponding author. E-mail: lu-caricio@bol.com.br

Received 13 July 2005

Accepted 30 November 2005
}

1999, Cover et al. 2003). vacA gene is present in all $H$. pylori strains and contains at least two variable parts. The s-region, which encodes the signal peptide, coexists as either s1 or s2 allelic types. Subtypes s1a, s1b, and s1c have been identified among type $\mathrm{s} 1$ strains. The $\mathrm{m}$-region (middle) occurs as $\mathrm{m} 1$ or $\mathrm{m} 2$ allelic types (Atherton et al. 1995, Papini et al. 2001). Production of VacA is related to the mosaic structure of vacA. In general, type $s 1 / \mathrm{m} 1$ and $\mathrm{s} 1 / \mathrm{m} 2$ strains produce high and moderate levels of toxin, respectively, whereas $\mathrm{s} 2 / \mathrm{m} 2$ strains produce little or no toxin (Atherton et al. 1995, 1997, Forsyth et al. 1998).

Recent in vitro work has demonstrated that strains with genotype vacA $\mathrm{s} 1 / \mathrm{m} 1$, but without $\mathrm{s} 2 / \mathrm{m} 2$ mediate channel activity and cellular vacuolation in intoxicated cells, which results in a detectable reduction of mitochondrial transmembrane potential and the release of cytochrome $\mathrm{c}$. This suggests a functional correlation between VacA channel activity and changes in mitochondrion membrane permeability (Willhite \& Blanke 2004).

A second disease-associated virulence factor is the cytotoxin-associated protein (CagA), a high molecular mass immunodominant protein $(140 \mathrm{KDa})$ that is part of the cag pathogenicity island (PAI) (Tummuru et al. 1995, Segal et al. 1999). Gene cagA is considered a marker for the presence of Cag PAI, which is associated with the most virulent $H$. pylori strains. Injected into the cytoplasm of the host cell, protein CagA plays an important 
role in the induction of cellular signaling and elicits multiple significant morphological changes, proliferation, and apoptosis (Stein et al. 2000, Hatakeyama 2003).

Studies conducted in several countries have shown that vacA-type s1 and cagA-positive $H$. pylori strains are associated with severe $H$. pylori-induced PUD (Atherton et al. 1995, van Doorn et al. 1998, Rudi et al. 2000, Catalano et al. 2001). Recent publications have also uncovered this association in Brazil (Mattar \& Sandanna 2000, Brito et al. 2000, Ashour et al. 2002).

In contrast, many reports from several parts of the world (Pan et al. 1997, 1999, Zheng et al. 2000, Backert et al. 2004) do not describe any significant association between genotypes (vacA type s1, cag A positive) and clinical responses among the various groups of infected patients with chronic gastritis, ulcer, and gastric cancer. Thus, existing data is contradictory and cannot explain the pathogenic role of $\mathrm{H}$. pylori in the development of different gastric diseases. Consequently, it might be useful to know the genetic diversity of $H$. pylori strains in North Brazil, a region with a high frequency of $H$. pylori-induced gastric disease.

The aim of this study was to determine the prevalence of gene cagA and vacA alleles in adult patients with gastritis and PUD in our population as well as the relation between cagA and/or vac A genotypes and histopathological data in the development of PUD.

\section{MATERIALS AND METHODS}

This study was approved by the Ethics Committee of Hospital Universitário João de Barros Barreto, Belém, PA, Brazil. All patients gave their informed consent to participate in the experiment.

Patients - This study was carried out at Hospital Universitário João de Barros Barreto, Hospital Universitário Betina de Ferro Souza, and Hospital Ofir Loiola from September 2002 to January 2003. During this period, gastric biopsies of 129 consecutive patients (median age, 44 years; range, $15-75$ years; 60 women and 69 men) who underwent gastric endoscopy due to different digestive disorders were obtained. None of the patients had received antimicrobial drugs, H2-receptor antagonists, acid pump inhibitors, nonsteroidal anti-inflammatory drugs, or any medication for at least 60 days before endoscopy.

During endoscopy, six biopsy fragments were taken from the stomach of each patient. Two antral and two corpus gastric biopsies were analyzed by histological methods, and two antrum specimens were also analyzed by molecular methods.

Histological evaluation - The biopsy specimens were fixed in $10 \%$ buffered formalin solution, embedded in paraffin, cut into sequential $0.4-\mu \mathrm{m}$ sections, and stained with hematoxylin and eosin (H\&E). The histopathological parameters were graded 0-3 using the criteria described in the updated Sydney classification system (Dixon et al. 1997) for analysis of chronic inflammation, polymorphonuclear activity, and bacterial density. Whenever present, intestinal metaplasia was typed as either complete, or mixed (complete and incomplete), or incomplete.
The presence of $H$. pylori in the sections was determined by using a modified Gram staining protocol and taking into consideration its morphological characteristics: curved and spiral form and intense blue colouring.

DNA isolation - Total DNA was extracted from frozen gastric biopsy specimens using the following procedure: $10 \mu \mathrm{l}$ of proteinase $\mathrm{K}$ and $300 \mu \mathrm{l}$ of lysis buffer $(200 \mathrm{mM}$ Tris- $\mathrm{HCl}, 25 \mathrm{mM}$ EDTA, $300 \mathrm{mM} \mathrm{NaCl}, 1.2 \%$ sodium dodecyl sulfate) were added to the biopsy specimens. The mixture was incubated at $55^{\circ} \mathrm{C}$ for $12 \mathrm{~h}$. The lysate was extracted with an equal volume of phenol-chloroform, precipitated with isopropanol, and washed with $70 \%$ ethanol. The pellet was dried and suspended in $200 \mathrm{ml}$ of sterile distilled water. DNA extracts were stored at $-20^{\circ} \mathrm{C}$.

PCR amplification and detection of amplified DNA products - One set of primers ( $\mathrm{p} 1$ and $\mathrm{p} 2$ ) (Hammar et al. 1992) that amplifies a gene fragment of $298 \mathrm{bp}$ present in all strains of $H$. pylori was used to detect bacterial DNA. Only positive samples were used for further study.

Amplification of vacA signal sequences and middle regions was performed by PCR with oligonucleotide primers described by Atherton et al. (1995). The strains were initially characterized as either type s1 or s2 and as either type $\mathrm{m} 1$ or $\mathrm{m} 2$. All s1 strain alleles were further characterized as either variant s1a or s1b. The previously described F1 and B1 primers were used (Tummuru et al. 1993) to detect $\operatorname{Cag} A$ as shown in Table I.

All PCR mixtures were prepared in a volume of $25 \mu \mathrm{l}$ containing $0.5 \mathrm{n} M$ of each primer; 1 X PCR buffer; $1.5 \mathrm{n} M$ $\mathrm{MgCl}_{2}$; sterilized water, $0.2 \mathrm{n} M$ deoxynucleoside; $1.25 \mu 1$ Taq DNA polymerase, and $2 \mu 1$ DNA sample. The mixtures were placed in a thermal cycler.

PCR amplification was performed under the following conditions: initial denaturation at $95^{\circ} \mathrm{C}$ for $2 \mathrm{~min}$ followed by 35 cycles of denaturation at $95^{\circ} \mathrm{C}$ for $1 \mathrm{~min}$, annealing and extension for $1 \mathrm{~min}$, and final extension at $72^{\circ} \mathrm{C}$ for 10 $\min$. Annealing temperatures were set at $58^{\circ} \mathrm{C}$ for primers VA3-F/VA3-R, VA4-F/VA4-R, F1/B1, and at $63^{\circ} \mathrm{C}$ for SS1F, SS3-F, SS2-F/ VA1-R. Negative and positive controls were used in all reactions.

PCR products were visualized by electrophoresis in $2 \%$ agarose gel, stained with ethidium bromide, and examined under UV illumination.

Statistical evaluation - Data were analyzed with Biostat version 3.0 software (Ayres et al. 2003). Chi-square tests, $\mathrm{G}$ test, and odds ratio (OR) with $95 \%$ confidence intervals $(95 \% \mathrm{CI})$ were used to assess the association between vacA alleles and cagA gene and the development of PUD. Histopathological parameters were analyzed by the Kruskal-Wallis test and Mann-Whitney test. Differences were considered statistically significant for $P$ values less than 0.05 .

\section{RESULTS}

Distribution of vacA alleles and cagA gene - Genotype vacA was detected in the antral mucosa of $91.5 \%$ $(118 / 129)$ of the patients studied. $96.6 \%(114 / 118)$ of patients were colonized by $H$. pylori strains harboring single vacA genotype (non-mixed infection). Among them, the s1 signal sequence was detected in $79.6 \%$ (94/114), of which $11.8 \%(14 / 114)$ had subtype s1a, and $67.8 \%$ (80/ 
TABLE I

Primers used in the amplification of vacA alleles and gene cagA of Helicobacter pylori

\begin{tabular}{|c|c|c|c|}
\hline $\begin{array}{l}\text { Amplified } \\
\text { region }\end{array}$ & Primer & Primer sequence & $\begin{array}{l}\text { Product } \\
\text { size (bp) }\end{array}$ \\
\hline \multirow[t]{2}{*}{$\overline{\mathrm{Ag}}$} & $\mathrm{P} 1$ & TGGCGTGTCTATTGACAGCGAGC & \\
\hline & $\mathrm{P} 2$ & CCTGCTGGGCATACTTCACCATG & 298 \\
\hline \multirow[t]{2}{*}{$\mathrm{m} 1$} & VA3-F & GGTCAAAATGCGGTCATGG & \\
\hline & VA3-R & CCATTGGTACCTGTAGAAAC & 199 \\
\hline \multirow[t]{2}{*}{$\mathrm{m} 2$} & VA4-F & CCATTGGTACCTGTAGAAAC & \\
\hline & VA4-R & GGAGCCCCAGGAAACATTG & 290 \\
\hline \multirow[t]{2}{*}{ s1 } & VA1-F & ATGGAAATACAACAAACCACAC & \\
\hline & VA1-R & CTGCTTGAATGCGCCAAAC & 259 \\
\hline \multirow[t]{2}{*}{ sla } & SS1-F & GTCAGCATCACACCGCAAC & \\
\hline & VA1-R & CTGCTTGAATGCGCCAAAC & 190 \\
\hline \multirow[t]{2}{*}{$\mathrm{s} 1 \mathrm{~b}$} & SS3-F & AGCGCCATACCGCAAGAG & \\
\hline & VA1-R & CTGCTTGAATGCGCCAAAC & 187 \\
\hline \multirow[t]{2}{*}{ CagA } & F1 & GATAACAGGCAAGCTTTTGAGG & \\
\hline & B1 & CTGCAAAAGATTGTTTGGCAGA & 349 \\
\hline
\end{tabular}

114) had subtype s1b. Subtype s2 was detected in $17 \%$ (20/114) patients. With regard to analysis of the middle region, alleles $\mathrm{m} 1$ and $\mathrm{m} 2$ were found in $75.4 \%(89 / 114)$ and $21.2 \%(25 / 114)$ patients, respectively.

Three combinations of signal sequences and middle region types were also identified. Among the 114 patients with non-mixed infection, strains with genotype s1a/m1 were found in $12.3 \%(14 / 114)$ patients, genotype with s1b$\mathrm{m} 1$ in $65.7 \%(75 / 114)$, and with genotype $\mathrm{s} 1 \mathrm{~b} / \mathrm{m} 2$ in $4.4 \%$ (5/114) patients. Genotype s $2 / \mathrm{m} 2$ was detected in $17.6 \%$ (20/114) patients. No strains presented genotype s/m1.

Multiple strain infection (colonization of the same patients by $H$. pylori strains harboring more than one vacA genotype) was detected in $3.4 \%$ (4/118) patients. Strains with $\mathrm{s} 1 \mathrm{~b} / \mathrm{m} 1$ - s $2 / \mathrm{m} 2$ genotype were detected in $2.6 \%$ (3/ 118) patients and with $\mathrm{s} 1 \mathrm{a} / \mathrm{m} 1-\mathrm{s} 2 / \mathrm{m} 2$ in $0.8 \%$ (1/118) patient. None of the patients with multiple strain infection were included in the analysis of the comparison of vacA genotype and cagA gene or their relationship to gastrointestinal diseases.

Gene cagA was detected in 92 out of 118 (78\%) patients infected with $H$. pylori; $75 \%$ (88/114) had no mixed infection. The presence of gene cag A was strongly associated with the $\mathrm{s} 1-\mathrm{m} 1$ vacA genotype $(\mathrm{G}=476.7598, \mathrm{p}<$ 0.001).

Relation between $H$. pylori genotypes and PUD Among the 129 patients selected, 69 (53.5\%) had gastritis, $29(22.5 \%)$ had gastric ulcer disease (GUD), and 31 (24\%) had duodenal ulcer disease (DUD). Seven of the patients with gastritis did not present $H$. pylori DNA, and four were colonized by two or more $H$. pylori strains. Two patients with GUD and two with DUD were $H$. pylori negative and none presented mixed infection.

The genotypes of $H$. pylori strains found in patients with different gastrointestinal diseases are given in Table II. Genotype s1/m1/cagA-positive is the most frequent among patients with DUD $(\mathrm{p}=0.01, \mathrm{OR}=7.09,95 \% \mathrm{CI}=$ $1.52-32.48)$ and GUD $(\mathrm{p}=0.00, \mathrm{OR}=7.09,95 \% \mathrm{CI}=1.52-$ 32.98). However, a separate analysis of the frequency of each allele in the different pathologies revealed an association between allele $\mathrm{s} 1 \mathrm{~b}$ and the presence of DUD $(\mathrm{p}=$ $0.00, \mathrm{OR}=15.09,95 \% \mathrm{CI}=1.88-120.85)$ and $\mathrm{GUD}(\mathrm{p}=0.00$, $\mathrm{OR}=13.35,95 \% \mathrm{CI}=1.66-107.40)$. In this study, allele s1a was not statistically associated with the occurrence of either DUD $(\mathrm{p}=0.61, \mathrm{OR}=4.00,95 \% \mathrm{CI}=0.31-50.23)$ or GUD ( $\mathrm{p}=0.29, \mathrm{OR}=6.00,95 \% \mathrm{CI}=0.54-66.17)$.

In relation to alleles $\mathrm{m} 1$ and $\mathrm{m} 2$, it was observed that the presence of allele $\mathrm{m} 1$ was associated with increased risk of DUD $(\mathrm{p}=0.00, \mathrm{OR}=7.66,95 \% \mathrm{CI}=1.65-35.48)$ and GUD ( $\mathrm{p}=0.00, \mathrm{OR}=7.09,95 \% \mathrm{CI}=1.52-32.98)$. Gene $\operatorname{cag} A$ also displayed an association with the development of $\operatorname{DUD}(\mathrm{p}=0.02, \mathrm{OR}=4.91,95 \% \mathrm{CI}=1.32-18.22)$ and $\mathrm{GUD}(\mathrm{p}$ $=0.00, \mathrm{OR}=7.09,95 \% \mathrm{CI}=1.52-32.98)$.

Relation between $H$. pylori genotypes and histological evaluation - All 114 patients who were infected by only one strain of $H$. pylori presented chronic gastritis in the antral region. However, the bacterium was observed in the gastric tissue of $80(70 \%)$ of the patients by the histologic method.

Comparing the degree of colonization, inflammation, and neutrophilic activity and vacA alleles of infecting strains, it was observed that patients infected with alleles $\mathrm{s} 1$ and $\mathrm{m} 1$ presented a degree of colonization, inflammation, and neutrophilic activity larger than that of allele s2 and $\mathrm{m} 2$ (Table III). However, the comparison of histological scores (colonization density, degree of inflammation, and neutrophilic activity) observed in patients infected by strains with subtypes allele s1a and those infected by s1b did not reveal a statistically significant difference (Table III). In relation to cagA positive strains, higher levels of colonization, inflammation, and neutrophilic activity were also verified in patients who were infected with strains of cagA-negative (Table IV).

Of the 114 patients infected by only one strain of $H$. pylori, $63(55.3 \%)$ presented incomplete intestinal metaplasia. The risk of developing metaplasia was larger in patients infected by strains that had allele s1a $(\mathrm{p}=0.02$, $\mathrm{OR}=7.20,95 \% \mathrm{CI}=1.53-33.84), \mathrm{s} 1 \mathrm{~b}(\mathrm{p}=0.00, \mathrm{OR}=6.66$, 
TABLE II

Distribution of genotypes of Helicobacter pylori strains (vacA and $\operatorname{cagA}$ ) found in patients with different infectious gastrointestinal diseases

\begin{tabular}{|c|c|c|c|c|c|c|}
\hline \multirow[b]{2}{*}{ Pathologies } & \multirow[b]{2}{*}{ VacA } & \multicolumn{4}{|c|}{$\operatorname{cag} A$ status } & \multirow[b]{2}{*}{ Total } \\
\hline & & Positive & $\%$ & Negative & $\%$ & \\
\hline Gastritis & S1a-m1 & 8 & 14 & 1 & 2 & 9 \\
\hline \multirow[t]{3}{*}{$(\mathrm{n}=58)$} & S1b-m1 & 28 & 48 & - & 0 & 28 \\
\hline & S1b-m2 & 1 & 2 & 2 & 3 & 3 \\
\hline & S2-m2 & 0 & - & 18 & 31 & 18 \\
\hline DUD & S1a-m1 & 2 & 7 & 0 & - & 2 \\
\hline \multirow[t]{3}{*}{$(\mathrm{n}=29)$} & S1b-m1 & 23 & 79 & 2 & 7 & 25 \\
\hline & S1b-m2 & 1 & 3.5 & 0 & - & 1 \\
\hline & $\mathrm{S} 2-\mathrm{m} 2$ & 0 & - & 1 & 3.5 & 1 \\
\hline GUD & S1a-m1 & 3 & 11 & 0 & - & 3 \\
\hline \multirow[t]{3}{*}{$(\mathrm{n}=27)$} & S1b-m1 & 22 & 81 & 0 & - & 22 \\
\hline & S1b-m2 & 0 & - & 1 & 4 & 1 \\
\hline & S2-m2 & 0 & - & 1 & 4 & 1 \\
\hline Total & & 88 & & & 26 & 114 \\
\hline
\end{tabular}

DUD: duodenal ulcer disease, GUD: gastric ulcer disease

TABLE III

Histological colonization density scores of Helicobacter pylori, and polymorphonuclear activity and chronic inflammation in patients infected with $H$. pylori strains with different vacA signal sequence and middle region type

\begin{tabular}{|c|c|c|c|c|c|c|c|}
\hline \multirow[b]{2}{*}{ Histopathological analysis } & \multicolumn{2}{|c|}{ Middle region } & \multicolumn{5}{|c|}{ Signal sequences } \\
\hline & $\mathrm{m} 1$ & $\mathrm{~m} 2$ & $\mathrm{P}^{\mathrm{I}}$ & $1 \mathrm{a}$ & s1b & s2 & $\mathrm{P}^{\text {II }}$ \\
\hline H. pylori colonization & $1(0-3)$ & $1(0-2)$ & $<0.05$ & $2(0-3)$ & $1(0-3)$ & $1(0-2)$ & $\begin{aligned}<0.05 a \\
<0.05 b \\
\\
\quad \mathrm{NS} c\end{aligned}$ \\
\hline Chronic inflammation & $2(1-3)$ & $1(1-3)$ & $<0.05$ & $2(1-3)$ & $2(1-3)$ & $1(1-3)$ & $\begin{aligned}<0.05 a \\
<0.05 b \\
\\
\quad \mathrm{NS} c\end{aligned}$ \\
\hline Polymorphonuclear activity & $2(1-3)$ & $1(1-2)$ & $<0.05$ & $2(1-3)$ & $2(1-3)$ & $1(1-2)$ & $\begin{aligned}<0.05 a \\
<0.05 b \\
\\
\quad \mathrm{NS} c\end{aligned}$ \\
\hline
\end{tabular}

I: Mann-Whitney test; II: Kruskal-Wallis test. Data represent the median score with the interquartile range in parentheses. NS: not significant; $a$ : comparison of alleles $s 1 a$ and $s 2 ; b$ : between alleles $s 1 b$ and $s 2$; $c$ : between alleles $s 1 a$ and $s 1 b$.

TABLE IV

Colonization density of Helicobacter pylori, chronic inflammation in patients, polymorphonuclear activity, and cagA status

\begin{tabular}{lccr}
\hline & \multicolumn{2}{c}{ Status cagA } & \multicolumn{1}{c}{ P } \\
\cline { 2 - 3 } Histopathological analysis & Positive & Negative & $<0.05$ \\
\hline H. pylori colonization & $1(0-3)$ & $1(0-2)$ & $<0.05$ \\
Chronic inflammation & $2(1-3)$ & $1(1-3)$ & $<0.05$ \\
Polymorphonuclear activity & $2(1-3)$ & $1(1-3)$ & \\
\hline
\end{tabular}

Kruskal-Wallis test. Data represent the median score with the interquartile range in parentheses.

$95 \% \mathrm{CI}=2.03-21.81), \mathrm{m} 1(\mathrm{p}=0.00, \mathrm{OR}=4.36,95 \% \mathrm{CI}=$ 1.64-11.54) and cagA-positive $(\mathrm{p}=0.00, \mathrm{OR}=8.12,95 \% \mathrm{CI}$ $=2.78-23.68$ ) when compared with strains with alleles $\mathrm{s} 2$, $\mathrm{m} 2$, and cagA-negative, respectively (Table V).

\section{DISCUSSION}

Infection by $H$. pylori is cosmopolitan and one of the most frequent in the whole world. The pathogen, a genetically diverse species with a high DNA recombination rate, may be involved in the complex variety of diseases in infected patients (Nomura et al. 1994, Dunn et al. 1997). Studies carried out in several countries have demonstrated differences in the distribution of vacA alleles and the presence of cagA gene in genotypes of strains of $H$. pylori and their association with the development of gastroduodenal diseases (Pan et al. 1997, 1999, Kidd et al. 1999, Morales-Espinosa et al. 1999, Zheng et al. 2000, Backert et al. 2004). 
TABLE V

Association between either the presence or absence of intestinal metaplasia and Helicobacter pylori vacA (s and $\mathrm{m}$ regions) and cagA genotypes

\begin{tabular}{|c|c|c|c|c|c|c|c|}
\hline \multirow[b]{2}{*}{ Metaplasia } & \multicolumn{3}{|c|}{ Signal sequence } & \multicolumn{2}{|c|}{ Middle region } & \multicolumn{2}{|c|}{$\operatorname{cag} \mathrm{A}$} \\
\hline & s1a & s1b & s2 & $\mathrm{m} 1$ & $\mathrm{~m} 2$ & Positive & Negative \\
\hline Present & 9 & 50 & 4 & 56 & 7 & 58 & 5 \\
\hline Absent & 5 & 30 & 16 & 33 & 18 & 30 & 21 \\
\hline Total & 14 & 80 & 20 & 89 & 25 & 88 & 26 \\
\hline
\end{tabular}

In this study we have found that $78 \%$ of the $H$. pylori species isolated from the patients had the vacA s1-m1 genotype, which is a higher value than described for other Brazilian cities, such as Belo Horizonte, MG, 35\% (Ashour et al. 2002), Bragança Paulista, SP, 59\% (Ribeiro et al. 2003), and Marília, SP, 59\% (Gatti et al. 2005). This result indicates that the genotype frequency of vacA in Brazilian regions is different from one to the other.

In the present study, evidence was found of the presence of multiple strains, based on vacA genotyping in $3.4 \%$ of the cases. Similar results were found by Ribeiro et al. (2003). Other studies of Brazilian patients found 13.4\% (Ashour et al. 2001) and 11\% (Gatti et al. 2005) coinfection by multiple strains. The prevalence of multiple $H$. pylori strains may be still underestimated, especially in areas with a high prevalence of $H$. pylori infection (van Doorn et al. 1998, Ashour et al. 2001). The sequencing of the s and $\mathrm{m}$ region of the $v a c A$ gene can define the degree of variation present and thus characterize the differences between the $H$. pylori species in the different regions.

In this study, we observed that genotype s1b-m1/ cagA-positive was the most frequent in patients with PUD. This variant is also more frequent in strains obtained from patients from Portugal, Spain, and African countries with historic, cultural and economic relationships with Brazil (Kidd et al. 1999, van Doorn et al. 1999, Noqueira et al. 2001).

High prevalence of genotype $\mathrm{s} 1 \mathrm{~b} / \mathrm{m} 1 /$ cagA-positive has also been detected in association with the development of PUD in north European patients (Nogueira et al. 2001, Tham et al. 2001).

Our data indicate that individuals colonized with s1b$\mathrm{m} 1 /$ cagA-positive $H$. pylori strains are at increased risk of developing peptic ulceration.

The association of the different vacA alleles and $\operatorname{cag} \mathrm{A}$ gene with the development of gastrointestinal diseases is contradictory (Pan et al. 1997, 1999, Zheng et al. 2000, Backert et al. 2004). Other Brazilian studies have also demonstrated an association between s1b-m1/cagA-positive and the presence of PUD (Evans et al. 1998, Ashour et al. 2002, Ribeiro et al. 2003, Gatti et al. 2005). However, another study carried out in Recife, PE, Northeast region of Brazil, did not correlate the predominance of allele $\mathrm{s} 1 \mathrm{~b}$ (90.7\%) with the development of PUD (Brito et al. 2003). These authors observed an association between the high predominance of gene $\operatorname{cag} \mathrm{A}$ and duodenal ulcer.
Similarly to what was observed for gene vacA, divergences in relation to the association of gene $\operatorname{cag} \mathrm{A}$ and the development of gastric diseases were also reported relative to the geographic distribution of gene $\operatorname{cag} \mathrm{A}$ in patients with PUD, which varied between 80 and $100 \%$. In Europe and North America, it has been demonstrated that infection by cagA-positive strains increases the risk of developing atrophic gastritis and gastric cancer; however, other studies carried out with European and Asian populations did not confirm these data (Maeda et al. 1998, Zheng et al. 2000, Backert et al. 2004, Zhou et al. 2004).

Persistent infection by $H$. pylori leads to an infiltration of neutrophils and lymphocytes in the gastric epithelia, causing a severe inflammatory activity, which can result in atrophic gastritis with development of intestinal metaplasia and displasia (Nogueira et al. 2001).

In our study, we also observed that alleles s1b, m1, and the presence of gene cagA presented high degrees of colonization, inflammation, and neutrophilic activity when compared to alleles s2, m2, and the absence of cagA.

Atherton et al. (1997) reported the association of allele $\mathrm{m} 1$ and histological alterations as related to an increase in epithelial damage (epithelial degeneration, mucus depletion, and microscopic erosions) in contrast to reports on allele m2. Similarly, Nogueira et al. (2001) observed that alleles s $1 \mathrm{~b}, \mathrm{~m} 1$ and the presence of gene cag A are associated to high degrees of gastric tissue inflammation and neutrophilic activity in Portuguese patients in relation to alleles $\mathrm{s} 2, \mathrm{~m} 2$, and the absence of $\operatorname{cagA}$.

The presence of intestinal metaplasia in the gastric mucosa was observed in $40 \%$ of the Portuguese and $60 \%$ of the Colombian population, in association with alleles s1b, m1, and the gene cagA (Nogueira et al. 2001). For patients with chronic gastritis from Belém, PA, the study by Aguiar et al. (2002) described $40 \%$ as having intestinal metaplasia and in our study $55 \%$ had the pre-malign lesion associated with $H$. pylori infection of the species containing alleles $\mathrm{s} 1 \mathrm{~b}, \mathrm{~m} 1$, and gene cagA.

Based on our study and others previously reported for the Brazilian population, we conclude that the strain containing genotypes $\mathrm{s} 1 \mathrm{~b}, \mathrm{~m} 1$, cagA-positive is the most prevalent one in patients with PUD. Our observations confirm the association of genotype $\mathrm{s} 1 \mathrm{~b} / \mathrm{m} 1 /$ cagA-positive of the infecting strain and the development of PUD. Thus, the detection of VacA and CagA, virulence markers described in several clinical outcomes may be used to help the treatment and prevention of $H$. pylori infection. 


\section{REFERENCES}

Aguiar FCD, Corvelo OCT, Araújo M, Cruz ME, Daibes S, Assumpção BM 2002. Expression of ABH e Lewis antigens in chronic gastritis and preneoplasic alterations in gastric mucosa. Arq Gastroenterol 39: 222-232.

Ashour AA, Magalhães PP, Mendes EN, Collares GB, de Gusmão VR, Queiroz DM, Nogueira AM, Rocha GA, de Oliveira CA 2002. Genotypes of vacA strains of Helicobacter pylori isolated from Brazilian adult with gatritis, duodenal ulcer or gastric carcinoma. FEMS Immunol Med Microbiol 1412: $1-6$

Atherton JC, Cao P, Peek Jr RM, Tummuru MK, Blaser MJ, Cover TL 1995. Mosaicism in vacuolations alleles of Helicobacter pylori. Association of specific vacA types with cytotoxin production and peptic ulceration. J Biol Chem 270: 17771-17777.

Atherton JC, Peek RM, Tham KT, Cover TL, Blaser MJ 1997. Clinical and pathological importance of heterogeneity in vacA the vacuolating cytotoxin gene of Helicobacter pylori. Gastroenterology 112: 92-99.

Ayres M, Ayres MJ, Ayres DL, Santos AS 2003. Bioestat 3.0 Aplicações Estatísticas nas Áreas das Ciências Biológicas e Médicas, 3rd ed., Sociedade Civil Mamirauá, MCT CNPq, Belém, 291 pp.

Backert S, Schwarz T, Miehlke S, Kirsch C, Sommer C, Kwok T, Gerhard M, Goebel UB, Lehn N, Koenig W, Meyer TF 2004. Functional analysis of the cag, pathogenicity island in Helicobacter pylori isolates from patients with gastritis, peptic ulcer, and gastric cancer. Infect Immun 72: 10431056.

Brito CAA, Silva LMB, Jucá N, Nilma C, Leal CN, Souza W, Queiroz D, Cordeiro F, Silva NL 2000. Prevalence of cagA and vacA genes in isolates from patients with Helicobacter pylori associated gastroduodenal diseases in Recife, Pernambuco, Brazil. Mem Inst Oswaldo Cruz 98: 817- 821.

Catalano M, Matteo M, Barbolla RE, Vega DEJ, Crespo O, Leanza AG, Toppor J, Antelo P 2001. Helicobacter pylori vacA genotypes, cagA status and ure A B polymorphism isolates recovered from an Argentine population. Diagn Microbiol Infect Dis 41: 205-210.

Cover TL, Blaser MJ 1992. Purification and characterization of the vacuolating toxin from Helicobacter pylori. J Biol Chem 267: 10570-10575.

Cover TL, Krishna US, Israel DA, Peek RMJR 2003. Induction of gastric epithelial cell apoptosis by Helicobacter pylori vacuolating cytotoxin. Cancer Res 63: 951-957.

Dixon MF, Genta RM, Yardley JH, Correa P 1997. Histological classification of gastritis and Helicobacter pylori infection: an agreement at last? The International Workshop on the Histopathology of Gastritis. Helicobacter (Suppl. 1): S17-24.

Dunn BE, Cohen H, Blaser MJ 1997. Helicobacter pylori. Clin Microbiol Rev 10: 720-741.

Evans DG, Queiroz DM, Mendes EN, Evans Jr DJ 1998. Helicobacter pylori cagA status and $\mathrm{s}$ and $\mathrm{m}$ alleles of vacA in isolates from individuals with a variety of $H$. pylori associated gastric diseases. J Clin Microbiol 36: 3435-3437.

Forsyth MH, Atherton JC, Blaser MJ, Cover TL 1998. Heterogeneity in levels of vacuolating cytotoxin gene (vacA) transcription among Helicobacter pylori strains. Infect Immun 66: 3088-3094.

Gatti LL, Fagundes E, Souza EK, Leite KR, de Souza Bastos EL, Vicentini LR, da Silva LC, Smith MA, Payao SL 2005. cagA vacA alelles and babA2 genotypes of Helicobacter pylori associated with gastric disease in Brazilian adult patients. Diagn Microbiol Infect Dis 51: 231-235.

Hammar M, Tyszkiewicz T, Wadstrom T, O’Toole PW 1992. Rapid detection of Helicobacter pylori in gastric biopsy material by polymerase chain reaction. J Clin Microbiol 30 : 54-58.

Hatakeyama M 2003. Helicobacter pylori CagA a potential bacterial oncoprotein that functionally mimics the mammalian Gab family of adaptor proteins. Microbes Infect 5: 143-150.

Kidd M, Lastovica AJ, Atherton JC, Louw JA 1999. Heterogeneity in the Helicobacter pylori vacA and cagA genes: association with gastroduodenal disease in South Africa? Gut 45: 499-502.

Maeda S, Ogura K, Yoshida H, Kanai F, Ikenoue T, Kato N, Shiratori Y, Omata M 1998. Major virulence factors, VacA and CagA, are commonly positive in Helicobacter pylori isolates in Japan. Gut 42: 338-343.

Mattar R, Laudanna AA 2000. Helicobacter pylori genotyping from positive clotests in patients with duodenal ulcer. Rev Hosp Clín 55: 155-160.

Morales-Espinosa R, Castillo-Rojas G, Gonzalez-Valencia G, Ponce de Leon S, Cravioto A, Atherton JC, Lopez-Vidal Y 1999. Colonization of Mexican patients by multiple Helicobacter pylori strains with different vacA and cagA genotypes. J Clin Microbiol 37: 3001-3004.

Nogueira C, Figueiredo C, Carneiro F, Gomes AT, Barreira R, Figueira P, Salgado C, Belo L, Peixoto A, Bravo JC, Bravo LE, Realpe JL, Plaisier AP, Quint WG, Ruiz B, Correa P, van Doorn LJ 2001. Helicobacter pylori genotypes may determine gastric histopathology. Am J Pathol 158: 647654.

Nomura A, Stemmermann GN, Chyou PH, Perez-Perez GI, Blaser MJ 1994. Helicobacter pylori infection and the risk for duodenal and gastric ulceration. Ann Intern Med 120: 977-981.

Pai R, Cover TL, Tarnawski AS 1999. Helicobacter pylori vacuolating cytotoxin disorganizes the cytoskeletal architecture of gastric epithelial cells. Biochem Biophys Res Commun 262: 245-250.

Pan ZJ, van der Hulst RW, Feller M, Xiao SD, Tytgat GN, Dankert J, van der Ende A 1997. Equally high prevalences of infection with cagA positive Helicobacter pylori in Chinese patients with peptic ulcer disease and those with chronic gastritis associated dyspepsia. J Clin Microbiol 35: 1344-1377.

Pan ZJ, van der Hulst RW, Tytgat GN, Dankert J, van der Ende A 1999. Relation between vacA subtypes, cytotoxin activity, and disease in Helicobacter pylori infected patients from the Netherlands. Am J Gatroenterol 94: 1517-1521.

Papini E, Zoratti M, Cover TL 2001. In search of Helicobacter pylori vacA mechanism of action. Toxicon 39: 1757-1767.

Ribeiro ML, Godoy AP, Benvengo YH, Mendonca S, Pedrazzoli Jr J 2003. Clinical relevance of the cagA, vacA and iceA 
genotypes of Helicobacter pylori in Brazilian clinical isolates. FEMS Immunol Med Microbiol 36: 181-185.

Rudi J, Kuck D, Rudy A, Sieg A, Maiwald M, Stremmel W 2000. Helicobacter pylori vacA genotypes and cagA gene in a series of $383 \mathrm{H}$. pylori positive patients. Z Gastroenterol 38: 559-564.

Segal ED, Cha J, Lo J, Falkow S, Tompkins LS 1999. Altered states: involvement of phosphorylated CagA in the induction of host cellular growth changes by Helicobacter pylori. Proc Natl Acad Sci USA 96: 14559-14564.

Stein M, Rappuoli R, Covacci A 2000. Tyrosine phosphorylation of the Helicobacter pylori CagA antigen after cag driven host cell translocation. Proc Natl Acad Sci USA 97: 12631268.

Taylor DN, Blaser MJ 1991. The epidemiology of Helicobacter pylori infection. Epidemiology 13: 42-59.

Tham KT, Peek Jr RM, Atherton JC, Cover TL, Perez-Perez GI, Shyr Y, Blaser MJ 2001. Helicobacter pylori genotypes, host factors, and gastric mucosal histopathology in peptic ulcer disease. Hum Pathol 32: 264-273.

Tummuru MK, Cover TL, Blaser MJ 1993. Cloning and expression of a high molecular mass major antigen of Helicobacter pylori: evidence of linkage to cytotoxin production. Infect Immun 61: 1799-1809.
Tummuru MKR, Sharma SA, Blaser MJ 1995. Helicobacter pylori picB, a homologue of the Bordetella pertussis toxin secretion protein, is required for induction of IL-8 in gastric epithelial cells. Mol Microbiol 18: 867-876.

van Doorn LJ, Figueiredo C, Megraud F, Pena S, Midolo P, Queiroz DM, Carneiro F, Vanderborght B, Pegado MD, Sanna R, De Boer W, Schneeberger PM, Correa P, Ng EK, Atherton J, Blaser MJ, Quint WG 1999. Geographic distribution of vacA allelic types of Helicobacter pylori. Gastroenterology 116: 823-830.

van Doorn LJ, Figueiredo C, Sanna R, Plaisier A, Schneeberger P, de Boer W, Quint W 1998. Clinical relevance of the cagA, vacA, and iceA status of Helicobacter pylori. Gastroenterology 115: 58-66.

Willhite CD, Blanke RS 2004. Helicobacter pylori vacuolating cytotoxin enters cells, localizes to the mitochondria, and induces mitochondrial membrane permeability changes correlated to toxin channel activity. Cell Microbiol 6: 143-154.

Zheng PY, Hua J, Yeoh KG, Ho B 2000. Association of peptic ulcer with increased expression of Lewis antigens but not cagA, iceA, and vacA in Helicobacter pylori isolates in an Asian population. Gut 47: 18-22.

Zhou W, Yamazaki S, Yamakawa A, Ohtani M, Ito Y, Keida Y, Hiashi H, Hatakeyama M, Si J, Azuma T 2004. The diversity of vacA and cagA genes of Helicobacter pylori in East Asia. FEMS Immunol Med Microbiol 40: 81-87. 